Volume. 4 Number. 2

Period: July - December 2020; page 47-53

p-ISSN : 2580-1112; e-ISSN : 2655-6669

Jurnal Ilmiah Keperawatan Orthopedi

Copyrighr@2020

(JIKO)

The author owns the copyright of this article

Journal homepage: https://ejournal.akperfatmawati.ac.id

DOI : $10.46749 /$ jiko.v4i2.40

\title{
The Relationship between Diet and Iron Deficiency Anemia in Post Partum Mothers in Dr. Zainoel Abidin Banda Aceh in 2019
}

\author{
Aida Fitri ${ }^{1}$, Darmawati ${ }^{2}$, Mariatul Kiftia ${ }^{3}$, Mira Rizkia ${ }^{4}$, Syahbandi $^{5}$ \\ ${ }^{1,2,3,4}$ Syiah Kuala University - Nursing Faculty, Indonesia \\ ${ }^{5}$ Regional General Hospital dr. Zainoel Abidin Banda Aceh, Indonesia \\ e-mail: aidafitri@unsyiah.ac.id
}

\begin{abstract}
One of the problems that contributed the largest numbers on mortality and maternal morbidity was anemia in the postpartum period. It is estimated that $50-80 \%$ of women suffer from anemia at 48 hours after birth. Anemia in women is associated with increased birth Infant Low Birth Weight (LBW), prematurity, maternal and child deaths and infections. This study aims to identify the relationship between dietary patterns and the incidence of iron deficiency anemia in post partum mothers at dr. Zainoel Abidin hospital Banda Aceh. This research is a quantitative study with a cross sectional study design. This research was conducted from June to September 2019 with 102 respondents selected through the non-probability sampling method. Respondents were postpartum mothers who were treated in room 2 (obstetric inpatient room). The study technique was carried out by giving a questionnaire and hemoglobin check has been carried out using HB meter. The data obtained were analyzed using the chi square statistical test with a confidence level of $95 \%$. This study found that the prevalence of anemia was $49,0 \%$ of respondents had mild anemia (Hb levels $9-10,9 \mathrm{gr} / \mathrm{dl}), 10,8 \%$ had moderate anemia $(\mathrm{Hb}$ levels 7-8,9 gr / dl), and 40,2\% not having anemia ( $\mathrm{Hb}$ levels >11 gr / dl). Overall, there is a significant relationship between dietary patterns and the incidence of anemia in postpartum mothers at dr. Zainoel Abidin Banda Aceh (p value 0,032).
\end{abstract}

Keywords: Diet Pattern, Iron Deficiency Anemia, postpartum

\section{Preliminary}

One of the problems that often occurs and accounts for the largest number of maternal mortality and morbidity is anemia in the postpartum period (Milman, 2015).

It is estimated that $50-80 \%$ of women experience anemia 48 hours after delivery (Rubio-álvarez et al, 2017). The World Health Organization (WHO) states that anemia in postpartum is where the $\mathrm{Hb}$ level is below $12 \mathrm{gr} / \mathrm{dl}$ (WHO, 2011).
Postpartum anemia can be caused by a physiological hemodelusion that occurs during pregnancy, a history of anemia in pregnancy and blood loss during the peripartum period. Bleeding is the condition most often associated with postpartum anemia (Rubio-álvarez et al, 2017)). It is estimated that $6 \%$ of births are complicated by blood loss of $>500 \mathrm{ml}$ (Carroli et al, 2008).

Globally, the most common cause of anemia is iron deficiency (Achebe \& Gafter-gvili, 2017). Iron deficiency anemia 
can occur due to lack of consuming iron-rich foods, consuming foods that inhibit iron absorption or gastrointestinal disease (Judd; 2010, silverberg, 2012, \& Vir; 2011). Iron deficiency anemia can affect the growth and development of babies during pregnancy and afterwards (Waryana; 2010).

It is estimated that there are approximately $38 \%$ or 32 million pregnant women worldwide who experience anemia (New \& Wirth; 2015). Globally, Southeast Asia has a high percentage of anemia, namely $48.2 \%$ (Ikeany \& Ibrahim; 2015). In Indonesia, the percentage of mothers with anemia in 2013 was $37.1 \%$ (Ministry of Health RI; 2013). So far, recent research has focused more on anemia in pregnancy, whereas anemia in postpartum has tended to be rarely noticed (Rakesh et al; 2014).

An antenatal health service improvement program has been launched by the Indonesian Ministry of Health through efforts to improve and modify service standards, but care for postpartum mothers remains the same as usual without any improvement efforts.

Recent studies have reported that postpartum iron deficiency and anemia occur more frequently than predicted. The prevalence of postpartum anemia in developing countries ranges from $50 \%$ to $80 \%$ (Milman; 2015). Meanwhile, in Aceh itself, research on anemia in the postpartum period is still rarely done and needs more attention so that this problem can be resolved immediately.

Maternal anemia is associated with an increase in low birth weight (LBW) births, prematurity, maternal and child mortality and infections (Waryana; 2010). In addition, the health status of the mother during the postpartum period affects the potential for the mother to breastfeed. When the mother is not able to breastfeed properly, it will increase other risks for the baby including anemia in infancy.

Research by Rakesh et al. (2014) in India, the prevalence of postpartum anemia is around $47.3 \%$. Anemia during pregnancy, profuse blood loss during labor, and inadequate intake of iron supplements were identified as factors associated with anemia during the postpartum period. Research by Garrido et al. (2017) in Madrid found that laceration of the birth canal, delivery by cesarean section, episiotomy, and ethnicity of the mother were the main risk factors for postpartum anemia.

\section{Method}

This research design used a crosssectional study approach. This research was conducted in the midwifery room (Arafah 3) Regional General Hospital dr. Zainoel Abidin Banda Aceh which was held from April 15 to August 152019 with 102 participants.

The research instrument used in this study was a questionnaire sheet about dietary patterns during pregnancy, amounting to 9 statement items and an $\mathrm{Hb}$ meter used to check the $\mathrm{Hb}$ levels of postpartum mothers.

Data collection in this study was carried out by direct interviews with patients. This data includes sociodemographic data, obstetric history, antenatal history, and dietary patterns.

The statistical test used is the paired t-test (paired $\mathrm{T}$ test), the degree of significance $\alpha=0.05$, so, if the p-value is $<0.05$, then reject $\mathrm{H} 0$ and If the $\mathrm{p}$-value is $\geq 0.05$, then accept $\mathrm{H} 0$.

\section{Result}

\section{Univariate Analysis}

Table. 1 Frequency Distribution of Univariate Analysis Results on Post Partum Mothers $(n=102)$

\begin{tabular}{llcc}
\hline No. & Demographic Data & Frequency & Percentage \\
\hline 1 & Prevalence Anemia & & \\
& Mild anemia & 50 & 49,0 \\
& Moderate anemia & 11 & 10,8 \\
& Severe Anemia & 0 & 0 \\
& No anemia & 41 & 40,2 \\
\hline \multicolumn{3}{c}{ Sociodemographic Data } \\
\hline
\end{tabular}




\begin{tabular}{|c|c|c|c|}
\hline 2 & $\begin{array}{l}\text { Mother's Age } \\
\text { No Risk } \\
\text { It's risky }\end{array}$ & $\begin{array}{l}68 \\
34 \\
\end{array}$ & $\begin{array}{l}66,7 \\
33,3 \\
\end{array}$ \\
\hline \multirow[t]{5}{*}{3} & \multicolumn{3}{|l|}{ Mother's Education } \\
\hline & $\begin{array}{l}\text { Elementary School / } \\
\text { equivalent }\end{array}$ & 2 & 2,0 \\
\hline & $\begin{array}{l}\text { Junior High School / } \\
\text { equivalent }\end{array}$ & 11 & 10,8 \\
\hline & $\begin{array}{l}\text { Senior High Schools } \\
\text { Equivalent }\end{array}$ & 41 & 40,2 \\
\hline & College / university & 48 & 47,1 \\
\hline \multirow[t]{6}{*}{4} & \multicolumn{3}{|l|}{ Mother's Job } \\
\hline & Government employees & 16 & 15,7 \\
\hline & Housewife & 65 & 63,7 \\
\hline & Entrepreneur & 15 & 14,7 \\
\hline & Does not work & 1 & 1,0 \\
\hline & Others & 5 & 4,9 \\
\hline \multirow[t]{4}{*}{5} & \multicolumn{3}{|l|}{ Family Income } \\
\hline & $\geq \mathrm{Rp} 2.700 .000 /$ month & 59 & 57,8 \\
\hline & $<\mathrm{Rp} 2.700 .000 /$ month & 43 & 42,2 \\
\hline & \multicolumn{3}{|c|}{ Obstetric Status } \\
\hline \multirow[t]{4}{*}{6} & Parity & & \\
\hline & Primipara & 25 & 24,5 \\
\hline & Multiparous & 70 & 68,6 \\
\hline & Grande Multipara & 7 & 6,9 \\
\hline \multirow[t]{3}{*}{7} & Type of Labor & & \\
\hline & Normal & 33 & 32,4 \\
\hline & Sectio Caesarea & 69 & 67,6 \\
\hline \multirow[t]{4}{*}{8} & Labor Difficult & & \\
\hline & There is & 61 & 59,8 \\
\hline & Not & 41 & 40,2 \\
\hline & \multicolumn{3}{|c|}{ Antenatal History } \\
\hline \multirow[t]{3}{*}{9} & Frequency ANC & & \\
\hline & $\leq 5$ kali & 32 & 31,4 \\
\hline & $>5$ kali & 70 & 68,6 \\
\hline \multirow[t]{6}{*}{10} & Place ANC & & \\
\hline & Doctor & 54 & 52,9 \\
\hline & Midwife & 27 & 26,5 \\
\hline & Hospital & 5 & 4,9 \\
\hline & Public health center & 15 & 14,7 \\
\hline & There is no & 1 & 1,0 \\
\hline 11 & \multicolumn{3}{|c|}{ Diet Practices } \\
\hline & Good & 41 & 40,2 \\
\hline & Enough & 43 & 42,2 \\
\hline & Less & 18 & 17,6 \\
\hline
\end{tabular}

Source: Primary Data (Processed, 2019)
Based on the table. 1 it can be concluded that as many as 50 people $(49.0 \%)$ of the respondents had mild anemia (Hb levels 9-10.9 g/ dl), the age of the most respondents was in the non-risk age category (aged 20-35 years) with a total of 68 people $(66.7 \%)$ and as many as 48 respondents $(47.1 \%)$ were mothers with the latest education from academia / college.

On average, 65 respondents $(63.7 \%)$ worked as housewives. Some of the respondents had a family income above the UMR ( $\geq$ IDR 2,700,000 / month), as many as 59 people (57.8\%).

Two thirds of the total respondents were mothers with multiparity parity status, as many as 70 people $(68.6 \%)$. Most of the respondents gave birth by using sectio caesarea as many as 69 people $(67.6 \%)$ and some had labor complications, namely as many as 61 people $(59.8 \%)$. The average respondent had a history of routine ANC> 5 times during pregnancy, as many as 70 people $(68.6 \%)$ and some of the respondents did ANC in a doctor's practice, as many as 54 people $(52.9 \%)$. Respondents have diet behavior in the sufficient category, namely as many as 43 people (42.2\%).

Table 2 The Relationship between Diet Practice Factors and Iron Deficiency Anemia Incidence in Post Partum Mothers at General Hospital dr. Zainoel Abidin Banda Aceh $(\mathrm{n}=102)$

\begin{tabular}{|c|c|c|c|c|c|c|c|c|c|c|}
\hline \multirow{3}{*}{$\begin{array}{l}\text { Diet } \\
\text { Practices }\end{array}$} & \multicolumn{10}{|c|}{ Iron Deficiency Anemia } \\
\hline & \multicolumn{2}{|c|}{ Mild Anemia } & \multicolumn{2}{|c|}{$\begin{array}{l}\text { Moderate } \\
\text { Anemia }\end{array}$} & \multicolumn{2}{|c|}{ Not Anemia } & \multicolumn{2}{|c|}{ Total } & \multirow[t]{2}{*}{$\alpha$} & \multirow[t]{2}{*}{ PValue } \\
\hline & $\mathrm{f}$ & $\%$ & $\mathrm{f}$ & $\%$ & $\mathrm{f}$ & $\%$ & f & $\%$ & & \\
\hline Good & 16 & 39,0 & 2 & 4,9 & 23 & 56,1 & 41 & 100 & \multirow{3}{*}{0,05} & \multirow{3}{*}{0,032} \\
\hline Enough & 22 & 51,2 & 8 & 18,6 & 13 & 30,2 & 43 & 100 & & \\
\hline Less & 12 & 66,7 & 1 & 5,6 & 5 & 27,7 & 18 & 100 & & \\
\hline Total & 50 & 49,0 & 11 & 10,8 & 41 & 40,2 & 102 & 100 & & \\
\hline
\end{tabular}

Source: Primary Data (Processed, 2019)

The table above shows dietary practices and the results of the chi square test carried out by giving a p-value less than 0.05 (rejecting $\mathrm{H} 0$ ), so it can be concluded that there is a relationship between dietary practice factors and the incidence of iron deficiency anemia in post partum mothers. at the General Hospital dr. Zainoel Abidin Banda Aceh.

\section{Discussion}

This study was conducted to find a correlation between dietary patterns and the incidence of iron deficiency anemia in postpartum women. Diet regulation 
that aims to establish or achieve the fulfillment of iron needs during pregnancy as well as cultural beliefs related to an iron-rich diet. After doing statistical tests, the results showed that there is a relationship between dietary patterns and the incidence of iron deficiency anemia in post partum mothers at dr. Zainoel Abidin Banda Aceh ( $p$ value 0.032 ). Conceptually, the most common causes of anemia are poor nutritional intake, iron deficiency and other micronutrients including folic acid, vitamin A and vitamin B12 (Di Renzo et al; 2015).

The use of blood-added supplements containing iron micronutrients during pregnancy is an alternative to prevent anemia in the postpartum period. WHO as a world health organization has also recommended pregnant women to take iron supplements to prevent complications of anemia during pregnancy and postpartum (Di Renzo et al; 2015)).

The results of this study found that as many as $75.5 \%$ of pregnant women said they consumed iron every day and $100 \%$ of all respondents believed that the need for nutritional intake during pregnancy was important for the fetus and itself. The results of this study are also supported by previous research conducted by Morsy \& Alhady (2014) on 400 pregnant women and found that poor nutritional intake has a correlation with the incidence of anemia in pregnancy.

An individual's dietary intake is also influenced by the cultural views held by that person. A study conducted in Nepal found that women in the mountainous regions of Nepal still consider traditions and beliefs as positive contributors to the continuation of pregnancy and childbirth, so they must be believed and applied (Kaphel et al; 2013).

The same is true in Aceh. Aceh is an area on the tip of Sumatra Island that still upholds the customs and values of the beliefs that are believed by the people (Ismail et al; 2018).

There are dietary recommendations and restrictions that pregnant Acehnese women must believe in carrying out their pregnancies. A study conducted by Puspitawati \& Batubara (2015) in North Aceh found that there are still many pregnant women who abstain from certain types of food. For example, not eating pineapple causing miscarriage, not eating sea fish such as cuttlefish, octopus or other types of fish that are oddly shaped, and not eating eggplant, jackfruit and gummy vegetables.

In this study, it was found that several views were deemed inappropriate to apply and required modification. As many as $57.8 \%$ of respondents believed that eating too much during pregnancy made the baby overweight, $64.7 \%$ of respondents believed that extra blood tablets could cause large babies, as many as $54.9 \%$ of respondents believed that consuming eggs during pregnancy could make babies large so that it is difficult to give birth, as many as $48 \%$ of mothers believe that consumption of milk during pregnancy can make the baby big, and as many as $44 \%$ of mothers believe that consumption of goat meat can make stomach pain and cramps.

Basically, giving iron tablets during pregnancy is done in an effort to prevent anemia. These tablets contain iron which can be absorbed by the body and is a source that provides iron to the body. The number of blood-added tablets recommended by the Indonesian Ministry of Health (2010) is a minimum of 90 tablets during pregnancy according to the needs of the mother, where pregnant women need about $60 \mathrm{mg}$ of iron from the beginning of pregnancy.

A pregnant woman needs this intake because of the decrease in hemoglobin concentration in maternal blood along with the increase in blood volume during pregnancy (Yehuda \& 
Mostofsky; 2010). Iron intake through iron tablets increases the source of hemoglobin-making substances so that there is a balance between hemoglobin levels and increased blood volume. This certainly does not increase the baby's weight in a negative context.

Apart from supplements, there are other ways that pregnant women can do to meet their iron needs. One of them is through food intake. Mothers must ensure that they consume a healthy and balanced diet so that they can meet the needs of vitamins, minerals and nutrients needed by mothers and babies (American Pregnancy Association; 2017).

A study conducted by Sirajuddin, Hadji, \& Musni (2014) in Makassar, Indonesia found that there was an effect of egg consumption on an increase in hemoglobin levels in pregnant women. As is well known, milk and eggs are proteins which are one of the factors that can facilitate iron absorption (Andriani \& Wirjatmadi; 2012). In addition, goat meat is one of the foods that contain heme iron.

Heme iron has a small iron content, but is well absorbed (Gluckman et al; 2015 \& Almatsier). On the basis of this understanding, it can be stated that these nutrient-rich foods are good for consumption during pregnancy and do not adversely affect the mother and fetus as long as they are consumed in reasonable quantities and limits.

\section{Conclusion}

One of the causes of anemia in the postpartum period is dietary patterns and eating behavior related to the culture of abstinence from food which is still developing in Aceh. Another thing related to postpartum anemia in dietary patterns is how to choose types of food sources that are not diverse, tend to only consume certain types of food sources.

The wrong way to process food ingredients, the wrong perception regarding iron supplements also contributes to the increasing prevalence of postpartum anemia.

\section{Suggestion}

The results of this study can be used as a source of information for researchers and readers regarding iron deficiency anemia in postpartum mothers. For the Regional General Hospital dr. Zainoel Abidin Banda Aceh, especially the midwifery department, in order to improve postpartum care services for postpartum mothers so that they can avoid various complications of childbirth including postpartum iron deficiency anemia. Improved services provided can also reduce the cost of education caused by the incidence of returning patients to the hospital due to certain conditions.

\section{Bibliography}

Achebe MM, Gafter-gvili A. (2017) How I treat anemia in pregnancy: iron, cobalamin, and folate. Blood;129(8):940-9.

Adriani M, Wirjatmadi B (2012). Pengantar Gizi Masyarakat. Jakarta: Kencana.

Almatsier, S. (2010).Prinsip Dasar Ilmu Gizi. Jakarta: PT Gramedia Pustaka Utama.

American Pregnancy Association. (2017) Where To Get Iron Naturally During Pregnancy. American Pregnancy. Available from: https://americanpregnancy.org/nat urally/get-iron-naturallypregnancyl

Carroli G, Cuesta C, Abalos E. (2008). Epidemiology of postpartum haemorrhage: a systematic review. Best Pract Res Clin Obstet Gynaecol. Elsevier Ltd;;22(6):999-1012.

Di Renzo GC, Spano F, Giardina I, Brillo E, Clerici G, Roura LC. (2015). Iron deficiency anemia in pregnancy. Women's Heal;11(6):891-900. 
Garrido CM, León J, Vidal AR, Garrido CM, Le J, Roman A. (2017). Maternal anaemia after delivery: prevalence and risk factors. $\mathrm{J}$ Obstet Gynaecol (Lahore). Informa UK Limited, trading as Taylor \& Francis Group;0(0):1-5.

Gluckman P, Hanson M, Seng CY, Bardsley A. (2015). Nutrition \& Lifestyle for Pregnancy \& Breastfeeding. United Kingdom: Oxford University Press.

Ikeanyi EM, Ibrahim AI. (2015). Does antenatal care attendance prevent anemia in pregnancy at term. Ikeanyi E M, Ibrahim A I - Niger J Clin Pract.18(3):323-8.

Ismail B, Sufi R, Joesoef MD, Leumiek HK, Nurdin. (2018). Ensiklopedia Budaya Adat Aceh. Banda Aceh: Majelis Adat Aceh.

Judd SJ. (2010). Blood and circulatory disorders. Ed. 3. Omnigraphics, Inc. United States: Omnigraphics, Inc. $162-165 \mathrm{p}$.

Kaphle S, Hancock H, Newman LA. (2013) Childbirth traditions and cultural perceptions of safety in nepal: Critical spaces to ensure the survival of mothers and newborns in remote mountain villages. Midwifery

Elsevier;29(10):1173-81.

Available from: http://dx.doi.org/10.1016/j.midw. 2013.06.002

Kemenkes RI. (2010). Pedoman pelayanan antenatal terpadu. Jakarta: Kementerian Kesehatan Republik Indonesia, Direktur Jenderal Bina Kesehatan Masyarakat; 1-40 p.

Kemenkes RI. (2013) Riset kesehatan dasar 2013. Jakarta: Badan Penelitian dan Pengembangan Kementerian Kesehatan RI.

Milman N. (2011) Postpartum anemia I: definition, prevalence, causes, and consequences. Ann Hematol. 90:1247-53.
Milman N. (2015) Postpartum anemia II: prevention and treatment. Ann Hematol. 91:143-54.

Morsy N, \& Alhady S. (2014). Nutritional status and socioeconomic conditions influencing prevalence of anaemia in pregnant women. 2014;3(7):5460.

New S, \& Wirth M. (2015). Anaemia, pregnancy, and maternal mortality: The problem with globally standardised haemoglobin cutoffs. BJOG.122(2):166-9.

Puspitawati, Batubara R. (2015). Persalinan Ma'blien pada Masyarakat Desa Sawang Kecamatan Samudera Aceh Utara. J Antropol Sos dan Budaya Pertolongan.1(2):124-32.

Rakesh P, Gopichandran V, Jamkhandi $\mathrm{D}$, Manjunath $\mathrm{K}$, George $\mathrm{K}$, Prasad J. (2014) Determinants of postpartum anemia among women from a rural population in southern India. Int $\mathrm{J}$ Womens Health. 395-400.

Rubio-álvarez A, Molina-alarcón M, Hernández-martínez A. (2017). Incidence of postpartum anaemia and risk factors associated with vaginal birth. Women and Birth. Australian College of Midwives;(7).

Silverberg DS. (2012). Anemia. Croatia: InTech. 233-240 p.

Sirajuddin S, Hadji V, Musni. (2014). The Effect of Eggs Consumption and Nutrition Counseling to the Increasing of Body Weight and Hemoglobin of Pregnant Women at Kassi-Kassi Health. Int J Sci Res Publ.4(4):1-9.

Vir SC (2011). Public health nutrition in developing countries. New Delhi: Woodhead Publishing India Pvt. Ltd.

Waryana. (2010). Gizi Reproduksi. Yogyakarta: Rajawali Press. 
World Health Organization. (2011). Haemoglobin concentrations for the diagnosis of anaemia and assessment of severity. Vitamin and Mineral Nutrition Information System (VMNIS). Available from: https://www.who.int/vmnis/indica tors/haemoglobin/en/

Yehuda S, Mostofsky D. (2010) Iron deficiency and overload from basic biology to clinical medicine. United States: Humana Press. 